\title{
THE ROLE OF ENGLISH IN THE LINGUISTIC LANDSCAPE OF KAZAN
}

\author{
I.S. Sharafutdinov \\ University of Regensburg \\ Regensburg, Germany \\ ilshat.sharafutdinov@stud.uni-regensburg.de
}

One of the ways to study the growing prominence of English in non-English speaking countries is to examine their linguistic landscapes. Of special interest are the bi- and multilingual regions, where English consistently finds its way amongst competition between the local and national languages. Present study explores how English proves itself in the linguistic landscape of Kazan (the Republic of Tatarstan, Russian Federation), where two languages, Russian and Tatar, have official status. Tatarstan, and especially its capital city of Kazan, is one of the leading financial, industrial, educational, cultural and touristic centres in Russia, which has recently hosted several world sport events and international festivals. This increased activity in the global arena has had an influence on the role of English in the area. Examining how English manifests against the background of the official bilingualism in the region may contribute to the discussion of spread of English on the world arena and possibilities to shift from bilingualism to multilingualism. The data was collected in May-July 2017 and includes 188 photos of all the signs found in the Bauman St., which is the central street in Kazan. The data was analysed with regard to several parameters: government or private producers of the sign, number of the languages and scripts on signs, code preference based on the semiotic features, presence and type of translation and transliteration, types of signs, types of establishments, type of information conveyed, etc. The results show that English is used intensively in the survey area, especially on the private signs, and the overall number of English texts outgrew the number of Tatar texts, despite the official status of the latter one. However, English was seldom found to be carrying complicated information and mostly was limited to simple grammar and vocabulary. Several idiosyncratic usages of English also did not speak in favour of its advanced usage. Apart from serving as an international language and conveying basic information to foreigners, English is found to be popular because of its high commercial and cultural prestige and strong association with high quality and high standards.

Keywords: linguistic landscapes, Kazan, English, Russian, Tatar.

For citation: Sharafutdinov I.S. The role of English in the linguistic landscape of Kazan. Istoricheskaya etnologiya - Historical Ethnology, 2018, vol. 3, no. 2, pp. 234251. DOI: 10.22378/he.2018-3-2.234-251 


\section{Introduction}

In recent years there has been growing interest to the study of languages in contact through the linguistic landscapes. Numerous works have been dedicated to the investigation of languages used on signs of cities found all around the world. Gorter \& Cenoz (2008) have shown that investigation of linguistic landscapes contributes into studying such prominent areas as effects of language policy, multilingualism and the spread of English.

The interest of scholars has often been attracted by the presence of big ethnic minority groups, comprised either of immigrants, like, for instance, in Edelman's study of Amsterdam (2010), or of local native peoples as seen in Cenoz \& Gorter's (2006) research organized in Friesland, the Netherlands, and the Basque Country, Spain. As those studies have shown, the native languages of minority groups increasingly have to compete and co-exist not only with the official dominating language of a country, but also with English. The role of English, as an international language, is increasing its presence in the linguistic landscapes worldwide (Wenzel, 1996; Griffin, 2004; Backhaus, 2006; Huebner, 2006; Cenoz \& Gorter, 2006). However, it is not only the status of the international language, but also its high prestige, symbolic value and association with the high standards of life, which make essential contribution into its wide visual presence (Ross, 1997; MacGregor, 2003). In many cases a multilingual setting of research areas offers additional possibilities for studying languages in contact.

One of the regions that deserves a closer look with respect to the multilingual setting, particularly language policy and the increasing influence of English, is the Republic of Tatarstan in Russia. According to the Census (2010) among more than 180 languages spoken in Russia the three most common languages are Russian ${ }^{1}$ (96\% of speakers), English (5\%) and Tatar (3\%). Whereas Russian and English are spread all over Russia, Tatar speakers are heavily concentrated in Tatarstan, home region for the biggest ethnic minority group in Russia. Tatars in that region constitute the ethnic majority (53\%) and Tatar language, as well as Russian, has official language status. Tatarstan, and especially its capital city of Kazan, is one of the leading financial, industrial, educational, cultural and touristic centres in Russia, which has recently hosted several world sport events and international festivals. This increased activity in the global arena has had an influence on the role of English in the area. Examining how English manifests against the background of the official bilingualism in the region may contribute to the discussion of spread of English on the world arena and possibilities to shift from bilingualism to multilingualism.

This article describes the study of the signs in Kazan. The city has long and rich history that goes over 1000 years back. Today Kazan is a multiethnic and multireligious metropolis with the population of over 1.2 million people. The

${ }^{1}$ In the present article the notion of 'Russian(s)' can refer to: 1 - the Russian language, or 2 - the Russian ethnicity, and then should not be confused with the citizenship of the Russian Federation. 
central shopping and touristic hub of Bauman Street was selected for the study. It is an area that has many shops, cafes, bars, restaurants and other establishments for leisure activities. The street attracts both locals and tourists. All the signs in this area were photographed and analyzed in order to answer the following research questions:

- What languages are found in the linguistic landscape of Kazan, and to what extent?

- What are the particular roles, weight and function of English among those languages? How is it presented on the bilingual and multilingual signs?

\section{Theoretical framework}

The study of the linguistic landscapes is a relatively new field and there have been different interpretations of the core notion of the linguistic landscapes in recent decades. As Gorter (2006: 1) notices, the term of the linguistic landscape can be used in a broader sense referring to a language situation in a certain country or an overview of the languages that are spoken in a certain area. However, the present paper, like many other works in the field, goes in line with a more specific definition offered particularly by Canadian researchers Landry and Bourhis in their seminal work (1997: 25):

The language of public road signs, advertising billboards, street names, place names, commercial shop signs, and public signs on government buildings combines to form the linguistic landscape of a given territory, region, or urban agglomeration.

This definition states clearly that linguistic landscape study is focused on the use of language on signs in public area. Gorter (2006: 2) underlines that this definition "refers to language that is visible in a specified area" and, thus, is related to its written form only.

Numerous studies done in the field of the linguistic landscapes lack agreement concerning aspects such as the survey area, the unit or item of analysis and the categorization of the collected data. The first question relates to the geographic boundaries of the area studied and the amount of signs collected within the area. One of the common approaches is selecting a street and including all the signs on that street into a corpus for the further analysis. As a rule, the preference is given to the commercial and entertainment localities simply because of the high density of signs found there. One of the issues that also arises here is the representativeness of the selected area(s) as of a whole city. Same applies to the signs which represent the area: should all of them be collected or should some selection criteria be applied? To make the decision it is necessary first to clarify the definition of a sign and this is another problem that requires special attention. Many linguistic landscape studies refer to the definition given by Backhaus (2006: 55):

A sign was considered to be any piece of written text within a spatially definable frame. The underlying definition is rather broad, including anything from handwritten stickers to huge commercial billboards outside a department 
store. items such as 'push' and 'pull' stickers at entrance doors, lettered foot mats, or botanic explanation plates on trees were considered to be signs, too [...] Each sign was counted as one item, irrespective of its size.

Cenoz \& Gorter (2006: 71) address a different approach and consider an entire establishment as one sign: "when a bank or a shop had its name on the front but also a number of advertising posters on the windows it was considered one sign". Similar choice is made by El-Yasin \& Mahadin (1996) who consider each store as one very large sign.

Defining the unit of survey is essential for the further counting of the units and interpreting the results. Two alternative solutions can be applied here. It is possible to count each and every sign (be it a single item or a whole establishment taken as one sign) or focus on "semantic rather than physical entities such as 'information units' (Monnier, 1989), 'messages' (CLF, 2000), or 'cases' (Griffin, 2004)" (Backhaus, 2006: 62).

Another topic for discussion is the categorization of signs. There are several parameters that require thorough attention. One of the most common distinctions is made between "signs placed by government agencies and signs placed by private persons" (Edelman, 2010: 19). The problematic point here is in the terminology used to refer to these two categories. Ben-Rafael et al. (2006), Cenoz \& Gorter (2006) differentiate between 'top-down' signs, referring in general to the signs initiated by government, and 'bottom-up' signs, produced or placed by private actors. Landry \& Bourhis (1997) and later Edelman (2010) refer to the dichotomy between "government" and "private" signs, which is also used in this study. It is noteworthy, that regardless of the terminology used, "the boundaries between the public and the private can be blurred [...], for example, when a state-owned establishment is privatized, or the other way round, when a private bank is nationalized" (Edelman 2010: 20).

Linguistic properties of text on signs might also lead to some problems in categorization. In the areas where two or more scripts take place ${ }^{2}$, "both language and script need to be taken into account" (Backhaus, 2006: 62). In the present study, a few examples of English words transliterated into the Cyrillic script were still referred to as English words due to their clear origin: e.g. «Тимбер» ('timber'). Similarly, Russian or Tatar words written in Latin script were not considered as English: e.g. "Zoloto" $=>$ «Золото» [gold]. On the other hand, scripts have been helpful in classifying proper names and words that sound or look the same in different languages, McArthur (2000: 38) calls them 'internationalisms'. Typical examples would be such forms as 'бар' [bar], 'паб' [pub], 'отель' [hotel], or proper names that are well established in several languages: Regina/Регина, Malibu/Малибу, Bristol/Бристоль. In those cases, the script might be of great help to identify the language used.

When more than one language is presented on a sign, it creates additional options to study arrangement of multilingual information, based on presence

\footnotetext{
${ }^{2}$ See Bangkok survey by Huebner (2006) or Tokyo survey by Backhaus (2006).
} 
and type of translation and semiotic features (size, spatial distribution of the texts). Reh (2004), Sebba (2007) and Edelman (2010) apply different terminologies that help to analyze how pieces of texts written in different languages are combined with each other. The present study follows the Edelman's (2010) approach who focused her analysis of multilingual texts on the presence of translation and distinguishes four different categories: 'word-for-word translation', 'free translation', 'partial translation' and 'no translation'. According to Scollon \& Scollon (2003), semiotic features are helpful in defining a system of preference of different languages that appear simultaneously on one sign. They claim that as far as the language that is written from left to right is concerned, the following preferences are observed: in a vertical alignment the above code is the preferred one, while in the horizontal alignment the preferred code is found on the left side. Another possibility would be locating the preferred code in the centre and the secondary code on the margins of the sign. Scollon \& Scollon add that the font size of the languages located on one sign also plays an important role. Even when one language is placed at the preferred position, the bigger font size of the other language(s) will outweigh the preferences of spatial distribution.

On the whole, the field of linguistic landscape studies displays several problematic theoretical aspects that play crucial role in shaping the present study's methodology.

\section{Previous studies of the linguistic landscapes of Tatarstan}

Investigation of the linguistic landscapes in Kazan and Tatarstan has already peaked interest among different scholars. Solnyshkina \& Ismagilova (2015: 37) discuss two important processes that influence the change of the linguistic landscape in Kazan. One of them is the 'westernization', which is described as the expansion of West-European cultural values and stereotypes into Russia, a common process in the country that has taken place in the recent 30 years after the break of the Soviet Union. This process involves numerous borrowings, when new foreignisms substitute old native words or bring new concepts unfamiliar to the local population. Foreignisms in the linguistic landscape of Kazan can be introduced with the help of calquing or transliteration, or used in their original forms, sometimes having lost the original meaning. Just the fact of having English in a company's name may attract customers as corresponding to a fancy "western" place.

Brand names in Kazan include not only foreignisms but also local native languages - Tatar and Russian. In fact, apart from westernization there is another strong process that influences the modernization of the linguistic landscape of the city, namely 'glocalization'. It manifests itself in the strengthening of the national traditions and the use of the native language (mostly Tatar) as an instrument to protect native ethnic interests and open ethnic authenticity to the external world (Solnyshkina \& Ismagilova, 2015: 36-37). In the present study, 
"Gulchatai" shop (original form «Гульчатай» which refers to a traditional Tatar name) or "Nogai" hotel serve as good examples.

One of the seminal works that deserves attention is the collection of essays by Gabdrakhmanova et al. (2016a) that are focusing on the different dimensions of the multilingualism in Tatarstan. In this collection the scientists from the Institute of History of the Academy of Sciences of the Republic of Tatarstan describe series of the ethnosociolinguistic studies that they started to carry in 2014 under the regional state program of "Preservation, study and development of the official languages of the Republic of Tatarstan and other languages in the Republic of Tatarstan in 2014-2020" (Gabdrakhmanova \& Makarova, 2016: 3).

As one of main directions in these studies they carried out large research on the linguistic landscapes of several cities in the Republic of Tatarstan, including Kazan (Gabdrakhmanova \& Makarova, 2016: 3). The authors of the research intended to answer the question to what extent the official languages are presented on the government and private signs, especially in the context of the official language policy norms and regulations. They also tried to understand the language attitudes and behaviour of the different participants of the linguistic landscapes. The results of this study show that Tatar language, despite its official status, is often neglected by the participants. It is out-grossed by Russian almost 16 times and more than twice by English. Both official languages are usually found on signs of government establishments and street signs, whereas private establishments in many cases do not include Tatar in their signs, especially travel agencies and shops selling electronics, clothes, perfume and jewelry.

In their comparative study Takhtarova et al. (2016) estimate the role and place of English in the linguistic landscapes of Paris, Berlin and Kazan. They underline the role of English as global language and its high prestige among the younger generation, particularly in Kazan. Language policy is mentioned to be one of the key factors that determines to which extent English might be integrated in the linguistic landscape of the city.

On the whole, linguistic landscape studies concerning Kazan and Tatarstan have similarly shown that English plays significant role in the region, mainly due to its global status and high prestige, especially among the younger generations. Two main processes, shaping the linguistic landscape of the area, were reported, namely 'westernization' and 'glocalization'. Language policy is another strong factor that may influence not only the use of the official languages but also the visual presence of English on signs.

${ }^{3}$ The name might refer to Nogai-Khan, a general of the Golden Horde, a state that preceded the Kazan Khanate, or to Nogai people - a Turkic ethnic group, relative to Tatars. 


\section{Sociolinguistic situation in the Republic of Tatarstan and its capital of Kazan}

The Republic of Tatarstan is located on the territory of ca. 68000 sq.km. at the confluence of Volga and Kama rivers. It is one of the most economically developed regions in Russia having rich natural resources, "powerful and diversified industry and high intellectual potential", and holding strong positions in agriculture (Official Tatarstan, 2017). According to the Census (2010), Tatarstan has a population of ca. 3.8 million people which is in general comprised of the three ethnic groups: $53.2 \%$ - Tatars, $39.7 \%$ - Russians, $3.1 \%-$ Chuvash. Traditionally Tatars are Muslims, whereas Russians and Chuvash confess Orthodox Christianity.

The capital of Tatarstan is Kazan - a city with over 1.1 million inhabitants. Ethnic make-up proportion of Kazan slightly differs from the overall statistical data on Tatarstan's population. Russians (48.6\%) and Tatars (47.6\%) are presented equally and the remainder represents other ethnicities, like Chuvash $(0.8 \%)$, Ukrainians (0.4\%), Mari (0.3\%) or Bashkorts (0.2\%) (Census, 2010). Kazan is "a big railway, motorway and airway hub and one of the largest river ports on the Volga" (Official Tatarstan, 2017). Industrial production takes an essential place in this city including machine engineering, aircraft construction, petroleum chemistry, textile and food processing. Kazan is also a significant science and research center, having dozens of higher education establishments, including the second oldest university in Russia - Kazan Federal University.

1000-year-old history, world sport and cultural events make Kazan one of the top tourist destinations in Russia. In 2016 it was visited by 250000 foreign visitors which was $6 \%$ more than the year before. In general, the annual rate of touristic growth equals $13.5 \%$ (Tatarstan Tourism, 2017).

Unlike English, which has started to show up actively in the language environment of Tatarstan relatively recently, Russian and Tatar - the two official languages in the region - have long, complex and competitive history. They do not share common origin: Russian is a Slavic language originating from the Indo-European language family. Tatar belongs to the Turkic language group. Since the fall of the Kazan Khanate, a medieval Bulgarian-Tatar Turkic state, in 1552 , the Tatar language "has been under significant stress from Russian" (Wertheim 2002: 4).

Sagitova (2016: 38) notes the prestige of the Russian language, which holds the status of the official language of the Russian Federation and is highly valued as an instrument of high social mobility and a component of social prestige. According to Census (2010), Russian is spoken by $97.5 \%$ of the Tatarstan population. The research carried out by Makarova (2016b: 102) shows that Russian remains to be a major language of communication at most working spheres in Kazan except the professions which are closely connected to the Tatar language and culture. 
According to the Ethnologue (Simons \& Fennig 2017), Tatar language is presented in all domains by all ages and meets positive attitudes by its speakers. The language has been actively used in literature, science and mass-media. Sagitova (2016: 39) underlines its symbolic value among the Tatar population ${ }^{4}$, especially in the home domain. Makarova (2016b: 102) draws attention to the symbolic weight of the Tatar language in the sphere of politics and public administration, as well as different sectors of the labour market where it can be used as the means of communication primarily between Tatars. Thus, Tatar language is often considered as an ethnic identity marker. In the context of the globalized world the original ethnicity component adds touristic attractiveness to the Tatar language.

English in Russia "falls under the category of the Expanding Circle ${ }^{5}$ countries", it "has restricted users" and is mainly used in "international commerce, tourism, study abroad, and science" (Ustinova 2005: 239). Proshina (2008: 125) remarks that English is the "language for intercultural and international business communication", specifies its role as a "major foreign language at school" and points out its pragmatic usage in commercial purposes as "English-flavored trade names are associated with prestige and good quality". Makarova (2016b: 119) reports that English is used fragmentarily in the advertisements in Kazan. In other her article, Makarova (2016a: 85) notes the increasing role of English since the break of the USSR among the people in Tatarstan (and in Russia, in general). Among the key factors supporting the positions of English she names the transformation of the education system, mass-media and leisure sectors, tourism development and job opportunities. Sagitova (2016: 40) signalizes to the essential importance of English for younger generation as the primary source for finding competitive information in the field of new technologies. It is associated with personal growth and advanced job opportunities.

Sagitova (2016: 40) remarks that social and economic transformation that followed the break of the Soviet Union, led to the change of the status and functions of English in Russia. From a limited functional sphere in the Soviet period it switched to the wide range of social functions driven by the new market conditions and the increase of the international contacts. She concludes that "English has become one of the main instruments of social and international mobility, professional communication in the technologically developed economic sectors, as well as the means of young person's personal growth".

Language policy plays an essential role in shaping the linguistic landscape of Kazan. According to the latest federal regulations set by the government of Russia, local regional languages can be used together with Russian in the sphere of visual communication which includes consumer services and toponymy.

${ }^{4}$ According to Census (2010), more than $90 \%$ of Tatars living in Tatarstan designated Tatar language as their native language, while $5 \%$ of Tatars chose Russian language. 3,5\% of Russians in Tatarstan reported they could speak Tatar.

${ }^{5}$ Kachru's Three-circle Model developed in 1985 (Kachru, 1985). 
However, unlike the mandatory nature of use of Russian language, regional languages appear only when the producer/seller decides to include another language in pair with Russian. "Thus, the federal legislation does not block the use of the regional languages in the sphere of visual communication, but also does not stimulate this process" (Gabdrakhmanova et al., 2016b: 130).

Tatarstan legislation slightly deviates from the national law. It offers similar regulations in the case of the language on tags, labels and instructions on goods and products where the producer is free to choose whether they want to give information not only in Russian, but also in an additional language. However, in the case of the visual information that comes on the government signs (posters, announcements, street names, sign-boards with names of government establishments) both official languages of Tatarstan are to be used. However, as the study by Gabdrakhmanova et al. (2016b) shows, these regulations are not always executed and, thus, carry a declarative character.

Recently the government of Tatarstan has started the program: "Preservation, study and development of the official languages of the Republic of Tatarstan and other languages in the Republic of Tatarstan in 2014-2020". The main focus of the program is the equal use of Russian and Tatar (50\% to $50 \%$ ) in the sphere of visual linguistic communication: road and street signs, state and municipal administration sector, info-communication sector and services sector.

In summer 2013, Kazan hosted the Universiade, one of the biggest multisport events in the world. Shortly before the event the Outdoor Advertising Bureau of Kazan recommended to the companies and organizations located in the immediate vicinity of the sport and touristic routes to include the information in English about working hours, address and activity profile on their establishments, together with the official languages, e.g.: Выход на посадку - Самолетка чыгү урыны - Departure Gate (Solnyshkina \& Ismagilova, 2015: 42).

\section{Methodology}

Shopping streets are often chosen in the studies of the linguistic landscapes, apparently due to the relatively higher amount of signs on the buildings. Following the sampling approach used in El-Yasin \& Mahadin (1996), Rosenbaum et al. (1977) and Cenoz \& Gorter (2006), I have selected the central street in Kazan - Bauman St. It is a pedestrian area that has many shops, cafes, bars and restaurants. The length of the street is around $1.3 \mathrm{~km}$. The beginning and the end of the street is determined by the side streets.

The data was collected by two field workers ${ }^{6}$ in May-July 2017. The field work was carried out on working days in the afternoon to make sure that all the

${ }^{6}$ Ramziia Bikchentaeva, M.A. in Sociology, and Anastasiya Kuzmina, student of the Kazan State University of Architecture and Engineering. 
establishments are open. The field workers were asked to take photos ${ }^{7}$ of all the signs they would notice and be able to read as passers-by, without going inside of the establishments. Movable objects, like public transport, cars, flyers, newspapers and other printed items were not taken into account. As a result, 188 photos were collected. Many photos have several signs in them. This explains why the overall number of the signs is bigger than the total amount of the photos. Some signs were too large to fit in one photo and are thus shown in several photos.

A combined approach was applied in the analysis of the data. First, following the definition of a sign introduced by Backhaus (2006), 419 signs were analyzed according to several criteria: government or private producers of the sign, number of the languages and scripts on signs, code preference based on the semiotic features of the bi- and multilingual texts, presence and type of translation and transliteration, types of signs, types of establishments (and a subtype involving the sectors of shop) and where the signs were put up.

After analyzing the data with regard to the listed variables, an additional approach was applied to specify the informative role of English and other languages in the area. The second approach focused on the 'types of information' that were conveyed by the languages. The notion of sign was reconsidered in favour of the definition offered by Cenoz and Gorter (2006), who determine an entire establishment as a single sign. All the photos were analyzed again and all the signs were encoded according to the types of information conveyed.

\section{Results}

The results of the study display the presence of eleven languages in the area, which can be split into three groups. The first group includes three most widespread languages that play an essential role in the construction of the local linguistic landscape: Russian, Tatar and English. The second group includes Italian, Chinese, French, Turkish and Korean languages that infrequently appeared on the signs. Their presence was relatively small when compared to the languages from the first group. The third group involves Japanese, Hind and Korean languages that were used singularly on the 'Sale' sign of a clothes shop.

The analysis of the results has shown the dominant presence of Russian in all types of signs and establishments. It was used solely and exclusively in almost half of all the signs and was the most preferred code in the nonmonolingual signs. Besides, it was never excluded from the signs containing Tatar and English. There were no idiosyncratic uses of Russian detected, and there were just few cases when it was written in the non-original Latin script.

Tatar language, due to its official status, was intensively used on the government signs, although still less often than Russian. Tatar was seldom used on

7 The camera used was a Canon 650D, apart from little exclusion: "EnglishFirst" centre and "FIFA" stand were photographed on a smartphone Samsung Galaxy S7 camera. 
the monolingual signs: in most of the cases it was paired with Russian on the bilingual signs or with Russian and English on the multilingual signs. On government signs Tatar served to convey different types of information, however, on private signs Tatar was used mostly to give information about working hours. It was the only type of information on the private signs where Tatar was intensively used. In company names Tatar was used far less often than English and especially Russian, and it almost never appeared in the promotional information. Additional information such as 'open'/'close' and 'pull'/'push' signs, information about the security measures and registered office address, etc. were mostly presented in Russian, although several cases of Tatar and English used in this role were also observed.

The two processes influencing the formation of the linguistic landscape in Kazan - westernization and glocalization (as discussed in Solnyshkina \& Ismagilova, 2015) - were also noticed in the present study. However, glocalization seemed to play a smaller role than westernization. Only several establishments actively promoted the local culture through the Tatar language or Tatar cultural phenomena (such as tubeteika cap or Gulchatai name), whereas most of others actively used English words and expressions on their signs. And as the examples of idiosyncratic use of English showed, those English texts may often be targeted at the local population or non-English tourists. This is further supported by the limited vocabulary that comprises most of the English texts on private signs.

English was no doubt the most successful foreign language in the area. As it has been noticed before, English was the only non-official and foreign language that appeared on government signs. Similarly as in the study by Cenoz \& Gorter (2006) it may be concluded that English forces its way into competition between the local and national languages. In fact, if English had been included into the street signs and memory tablets together with Russian and Tatar, as it was observed on the directory arrows, then it would have been used almost as often as Tatar. Nevertheless, being present on the quarter of the government signs speaks about the desire of the local government to add 'international' and 'cosmopolitan' flavor to the city with the help of English, as it was observed, for instance, in Wenzel (1996) or Huebner (2006).

On the private signs, English celebrated big success. Despite the gap between the presence of English and Tatar on the government signs, the large prevalence on the private signs granted the overall numerical superiority of English signs over signs with Tatar. Unlike Tatar, English was given independence to be exclusively used on monolingual signs. English appeared alone on $15 \%$ of all private monolingual signs - infrequent when compared to Russian, but still five times more often than monolingual use of Tatar. Whereas Tatar most often duplicated Russian texts on bilingual signs, unique information was often presented in English texts on non-monolingual signs with no equivalent translation in Russian or Tatar. Moreover, Tatar was placed second in most of 
the cases, while English was the preferred language on $30 \%$ of the private nonmonolingual signs.

Functions of Tatar and English also differed sufficiently. As it has been mentioned above, Tatar was used to a large extent to convey information about 'working hours'. Surprisingly, despite the recommendations from the Outdoor Advertising Bureau of Kazan which were mentioned in Solnyshkina \& Ismagilova (2015: 42), information about working hours and address was seldom duplicated in English. Most often this language was used in company names and promotional information. In her Tokyo study, MacGregor (2003: 22) noticed that English was used by local companies because of its association with such positive images as "high quality, high status, high society". Similar observation was made by Ross (1997) in his Milan study. He pointed out that even erroneous usage of English was still associated with prestige. The linguistic idiosyncrasies were found in this study as well and the results of the study showed that a similar situation is observed in Kazan today, where many local establishments are presented partly or entirely by English names. On the other hand, the choice of English could also be motivated by its status of international language, e.g. on the souvenir shop names.

Several idiosyncratic uses of English on the signs concerned such linguistic levels as orthography, lexis and syntax. One of the typical examples would be the omission of spaces between two words, e.g.: "Incity", "STRONGFIT", "KILLFISH". Sometimes punctuation marks were omitted, like a hyphen in "pan asian cafe'" (correct form is "pan-Asian' or 'Pan-Asian'") or apostrophe in the cyrillized version of "McDonald's" - «Макдоналдс». Those two examples also display another linguistic deviation - non-use of upper case letters: 'a' in 'Asian' and 'д' $<\mathrm{d}>$ in «Макдоналдс». Some orthographic idiosyncrasies were caused by puns, e.g.: "Woki Toki" is a homophone to the popular English word "walkietalkie'. However, the name of the café refers to the Chinese noodles that are cooked in a 'wok' - a traditional Chinese skillet. Another example of using a pun is the name of the shop that sells contact lenses "Lens Go", which is assonant with another popular English expression 'let's go'. Another orthographic idiosyncrasy observed was the use of the atypical abbreviation 'Str.' on the directory arrows, e.g. "Bauman Str.", "Peterburgskaya Str.", which is more common for German language. An example of syntactic idiosyncrasy would be the name of "Museum Tesla". In this case the noun modifier 'Tesla' stands in post-position which is a typical feature of the Russian language, while in a standard English an ascriptive noun would stand in pre-position: 'Tesla museum'.

Idiosyncrasies were found on the lexical level as well. An unusual collocation "Caution Stairways" was found on the door of a jewelry shop. The sticker actually is intended to draw the customer's attention to watch the step at the entrance door. Another rather idiosyncratic and creative word combinations

8 Available in: http://www.oed.com/view/Entry/259649?redirectedFrom=PanAsian\# eid (accessed: 20.03.2018). 
were found in the names of two establishments: "Hobby games" shop that was selling board games, and "Pavlov Studio - dance of hair" hair salon.

Some of these idiosyncrasies can be explained by language interference, for example, both in the Russian and Tatar variants of the English word 'Asian' the initial letter is written in lower case. Another possible reason for these linguistic idiosyncrasies could be down to low competence of English around the local population. On the one hand, the sign producers might be not aware of their idiosyncratic use of English (e.g. "Caution Stairways" sign). On the other hand, most readers of the signs may not be able to accurately identify incorrect usage of English and could take the given forms as granted, particularly where an English name also confers an international company that might have an implied or perceived authority on the accepted uses of English.

It is noteworthy, that linguistic idiosyncrasies were also found in the Tatar texts. For example, incorrect translation of the phrase "Shuttle to the Stadium". The Tatar analogue of the phrase «Трансфер стадионына» given on the sign actually means 'to the transfer stadium' because 'трансфер' [transfer] stands in the modifying position. Another few striking orthographic idiosyncrasies were an extra letter 'c' added in the word 'көннәрсе' [days] on the sign of a hat shop (correct form - 'көннәре'), and omission of the same letter 'c' in the word 'тәнәфесез' [without a break] on the sign of the "Bristol" shop (correct form 'тәнәфессез').

One way or another, English did not carry complicated information, not counting few exceptions on the government signs that provided informational background on historical sights and a map of Kazan. It either served as lingua franca for conveying basic information to foreigners (using basic vocabulary and internationalisms, such as 'bar', 'cafe', 'hotel') or formed a prestigious cosmopolitan image to the Russian and Tatar speakers.

In the foreseeable future, there is hardly any other foreign language that can challenge the position of English in the linguistic landscape of the studied area. Italian that was used more often than other languages is strictly bound to the fashion industry and does not seem to spread its influence beyond this sphere. Chinese appeared surprisingly in the role of providing promotional information on three different establishments. While the frequency of use was low, the detail of the content included indicates that Chinese has the potential to increase its visual presence in the area, particularly as the number of Chinese tourists grows in Russia.

Other languages do not seem to play any significant role and might appear in future anecdotally in the form of company name or specific cases such as the 'sale' sign of the "Incity shop" in this study that included nine different languages.

It is hard to predict, to what extent English may challenge the positions of the official languages in future. If it is added to street signs and memory tablets it will achieve a similar position across government signs as the official languages. The possibility of such a scenario does not seem to be unreal, as, for 
instance, the public transport in Kazan already uses announcements in all three languages: Russian, Tatar and English.

As for the positions of English on private signs there are several factors that may influence the present-day situation. First of all, it is the number of foreign tourists visiting the city. Tourism is expected to grow in Kazan, and with it, the likelihood of the use of English language on commercial signs. Secondly, the language competence among the local population and the visitors from other parts of Russia might also play an essential role. The higher the competence, the more chances for advanced English to be used, and the fewer chances for linguistic idiosyncrasies to appear. The third factor is connected with the first one and relates to the language policy. The city's authorities may contribute a lot into the further promotion of English if they continue integrating it on government signs and giving recommendations about its usage on private signs. Finally, the socio-economic positions of English-speaking countries and their relationships with Russia might also influence the attitudes towards English among the local population, and in turn, change cultural attitudes towards the use of English.

\section{Recommendations for future research}

The present research findings suggest the following directions for future studies:

- Linguistic landscapes in other districts of Kazan (residential and industrial areas) and Tatarstan: investigation of the non-touristic and rural areas might display less prominent presence of English and possibly stronger positions of Tatar (especially in the country side areas);

- Present research can be used as the background for a diachronic study in the future. It will be interesting to see, to what extent and in what role English will be presented in the linguistic landscape of Kazan in several years, and whether any other language, especially Chinese, will strengthen its position;

- The continuing increase of the prominence of English could possibly be studied as the factor that signals the shift from bilingualism to multilingualism in the region;

- Further examination of idiosyncratic uses of English, especially those made up by someone's creativity, might give interesting insights into the study of language contact.

\section{REFERENCES}

1. Backhaus P. Linguistic landscapes: A comparative study of urban multilingualism in Tokyo. Clevedon, Multilingual Matters, 2006. (In English)

2. Ben-Rafael E., Shohamy E., Amara M.H. \& Trumper-Hecht N. Linguistic landscape as symbolic construction of the public space: The case of Israel. International Journal of Multilingualism, 2006, no. 3(1), pp. 7-30. (In English)

3. Cenoz J. \& Gorter D. Linguistic landscape and minority languages. International Journal of Multilingualism, 2006, no. 3(1), pp. 67-80. (In English) 
4. Census. 2010. All-Russia Census results in the web-site of the Russian Federal State Statistics Service. Available in: http://www.gks.ru/free_doc/new_site/ perepis2010/croc/perepis_itogi1612.htm (accessed 05.06. 2017).

5. CLF (Conseil de la langue française). La langue de l'affichage à Montréal de 1997 à 1999. Quebec, Conseil de la langue française, 2000. (In French)

6. Edelman L. Linguistic landscapes in the Netherlands. A study of multilingualism in Amsterdam and Friesland. PhD-Thesis. Utrecht, LOT, 2010. Available in: http://www.lotpublications.nl/Documents/261_fulltext.pdf (accessed 05.07. 2017).

7. El-Yasin M.K. \& Mahadin R.S. On the pragmatics of shop signs in Jordan. Journal of Pragmatics, 1996, no. 26(3), pp. 407-416. (In English)

8. Gabdrakhmanova G. \& Makarova G. Vvedeniye [Introduction]. Gabdrakhmanova G.H., Makarova G.I., Mukhametzyanova A.R. (eds.) Gosudarstvenniye yaziki Respubliki Tatarstan: mnojestvennost' izmereniy [Official languages in the Republic of Tatarstan: Multiplicity of Dimensions]. Kazan, RT AS Sh. Marjani Institute of History, 2016, pp. 121-163. (In Russian)

9. Gabdrakhmanova G.F., Makarova G.I., Mukhametzyanova A.R. (eds.) Gosudarstvenniye yaziki Respubliki Tatarstan: mnojestvennost' izmereniy [Official languages in the Republic of Tatarstan: Multiplicity of Dimensions]. Kazan, RT AS Sh. Marjani Institute of History, 2016. (In Russian)

10. Gabdrakhmanova G., Makhmutov Z., Sagdiyeva E. Etnoyazikovoy landshaft gorodov Respubliki Tatarstan [Ethnolinguistic landscape of the cities of the Republic of Tatarstan]. Gabdrakhmanova G.H., Makarova G.I., Mukhametzyanova A.R. (eds.) Gosudarstvenniye yaziki Respubliki Tatarstan: mnojestvennost' izmereniy [Official languages in the Republic of Tatarstan: Multiplicity of Dimensions]. Kazan, RT AS Sh. Marjani Institute of History, 2016, pp. 121-163. (In Russian)

11. Gorter D. Introduction: The study of the linguistic landscape as a new approach to multilingualism. International Journal of Multilingualism, 2006, no. 3(1), pp. 1-6. (In English)

12. Gorter D. \& Cenoz, J. Knowledge about language and linguistic landscape. Cenoz J. \& Hornberger N.H. (eds.) Encyclopedia of Language and Education. Vol. 6. Knowledge about Language. New York, Springer Publ., 2008, pp. 343-357. (In English)

13. Griffin J.L. The presence of written English on the streets of Rome. English Today, 2004, no. 20 (2), pp. 3-7. (In English)

14. Huebner T. Bangkok's linguistic landscapes: Environmental print, codemixing and language change. International Journal of Multilingualism, 2006, no. 3(1), pp. 3151. (In English)

15. Kachru B.B. Standards, codification and sociolinguistic realism. The English language in the outer circle. Quirk R. \& Widdowson H.G. (eds.) English in the World: Teaching and learning the language and literatures. Cambridge, Cambridge University Press, 1985, pp. 11-30. (In English)

16. Landry R. \& Bourhis R.Y. Linguistic landscape and ethnolinguistic vitality: An empirical study. Journal of Language and Social Psychology, 1997, no. 16, pp. $23-$ 49. (In English)

17. MacGregor L. The language of shop signs in Tokyo. English Today, 2003, no. 19 (1), pp. 18-23. (In English)

18. Makarova G. Yazikoviye praktiki molodeji v dosugovih prostranstvah Kazani [Language use by youth in the leisure areas of Kazan]. Gabdrakhmanova G.H., 
Makarova G.I., Mukhametzyanova A.R. (eds.) Gosudarstvenniye yaziki Respubliki Tatarstan: mnojestvennost' izmereniy [Official languages in the Republic of Tatarstan: Multiplicity of Dimensions]. Kazan, Institut Istorii im. Sh. Mardzhani AN RT, 2016a, pp. 104-120. (In Russian)

19. Makarova G. Etnoyazikovoye povedeniye molodih kazantsev (po materialam poluformalizovannih interv'yu) [Ethnolinguistic behavioour of the young Kazan citizens (a case study of semi-formalized interviews)]. Gabdrakhmanova G.H., Makarova G.I., Mukhametzyanova A.R. (eds.) Gosudarstvenniye yaziki Respubliki Tatarstan: mnojestvennost' izmereniy [Official languages in the Republic of Tatarstan: Multiplicity of Dimensions]. Kazan, Institut Istorii im. Sh. Mardzhani AN RT, 2016b, pp. 85-103. (In Russian)

20. McArthur T. Interanto: The global language of signs. English Today, 2000, no. 16 (1), pp. 33-43. (In English)

21. Monnier D. Langue d'accueil et langue de service dans les commerces à Montréal. Quebec, Conseil de la langue française, 1989. (In French)

22. Official Tatarstan. Official web-site of the Tatarstan Government. 2017. Available in: http://tatarstan.ru/eng/about/welcome.htm (accessed 01.06.2017). (In English)

23. Proshina Z. English as a Lingua Franca in Russia. Intercultural Communication Studies, 2008, no. XVII (4), pp. 125-140. (In English)

24. Reh M. Multilingual writing: A reader-oriented typology - with examples from Lira Municipality (Uganda). International Journal of the Sociology of Language, 2004, no. 170, pp. 1-41. (In English)

25. Rosenbaum Y., Nadel E., Cooper R.L. \& Fishman J.A. English on Keren Kayemet Street. Fishman J.A., Cooper R.L. \& Conrad A.W. (eds.) The spread of English: The sociology of English as an additional language. Rowley, MA, Newbury House, 1997, pp. 179-194. (In English)

26. Ross N. Signs of international English. English Today, 1997, no. 13 (2), pp. 29-33. (In English)

27. Sagitova L. Dinamika yazikovih protsessov v Tatarstane: konkurentsiya yazikov v molodejnoy srede v usloviyah modernizytsii I globalizatsii [The dynamics of language processes in Tatarstan: language competition within the youth environment in the context of modernization and globalization]. Gabdrakhmanova G.H., Makarova G.I., Mukhametzyanova A.R. (eds.) Gosudarstvenniye yaziki Respubliki Tatarstan: mnojestvennost' izmereniy [Official languages in the Republic of Tatarstan: Multiplicity of Dimensions]. Kazan, Institut Istorii im. Sh. Mardzhani AN RT, 2016, pp. 5-42. (In Russian)

28. Sebba M. Multilingualism, multimodality and mixed-language texts. Paper presented at the 6th International Symposium on Bilingualism. Hamburg, 2007. (In English)

29. Scollon R. \& Scollon S.W. Discourses in Place: Language in the Material World. London and New York, Routledge, 2003. (In English)

30. Simons G.F. \& Fennig C.D. (eds.) Ethnologue: Languages of the World, Twentieth edition. 2017. Dallas, Texas: SIL International. Available in: http://www.ethnologue.com (accessed 25.05. 2017). (In English)

31. Solnyshkina M.I. \& Ismagilova A.R. Linguistic Landscape. Westernization and Glocalization: the case of Kazan, Republic of Tatarstan. XLinguae Journal, 2015, 
vol. 8, issue 2. Available in: http://www.xlinguae.eu/files/xlinguae2_2015_4.pdf (accessed 17.07.2017). (In English)

32. Takhtarova S., Kalegina T., Yarullina F. The role of English in shaping the linguistic landscape of Paris, Berlin and Kazan. Procedia - Social and Behavioral Sciences, 2015, no. 199, pp. 453-458. (In Russian)

33. Tatarstan Tourism. Official website of the State Committee for Tourism in the Republic of Tatarstan. 2017. Available in: http://tourism.tatarstan.ru/rus/file/pub/ pub_857409.pdf (accessed 11.06. 2017). (In Russian) (In English)

34. Ustinova I. English in Russia. World Englishes, 2005, vol. 24, issue 2, pp. 239-252. (In English)

35. Wenzel V. Reclame en tweetaligheid in Brussel: Een empirisch onderzoek naar de spreiding van Nederlandstalige en Franstalige affiches. Brusselse thema's 3. Brussels, Vrije Universiteit, 1996, pp. 45-74. (In Dutch)

36. Wertheim S. Language "Purity" and the De-Russification of Tatar. UC Berkeley: Berkeley Program in Soviet and Post-Soviet Studies. 2002. Available in: https://escholarship.org/uc/item/81z5217g (accessed 11.10. 2017). (In English)

About the author: Ilshat S. Sharafutdinov is M.A., doctoral candidate at the Department of English Linguistics, University of Regensburg (Universitätsstraße 31, Regensburg 93053, Germany); ilshat.sharafutdinov@stud.uni-regensburg.de

\title{
РОЛЬ АНГЛИЙСКОГО ЯЗЫКА В ЯЗЫКОВОМ ЛАНДШАФТЕ Г. КАЗАНИ
}

\author{
И.С. Шарафутдинов \\ Университет Регенсбурга \\ Регенсбург, Германия \\ ilshat.sharafutdinov@stud.uni-regensburg.de
}

Одним из способов изучения распространения английского языка в неанглоязычных странах является исследование их языковых ландшафтов. Особый интерес представляют би- и мультилингвальные регионы, где английский язык составляет конкуренцию местным и общенациональным языкам. В данной работе исследуется то, как английский язык проявляет себя в языковом ландшафте г. Казани (Республика Татарстан, Российская Федерация), в которой два языка - русский и татарский, имеют официальный статус. Татарстан, и особенно его столица Казань, является одним из ведущих финансовых, промышленных, образовательных, культурных и туристических центров в России. В последние годы она приняла ряд мировых спортивных мероприятий и международных фестивалей. Возросшая активность на мировой арене оказала влияние на роль английского языка в этом регионе. Исследование того, как английский язык проявляется на фоне официального двуязычия в регионе, будет способствовать дальнейшему обсуждению вопросов его распространения в мире и возможностей перехода от двуязычия к многоязычию. Данные для исследования были собраны в мае-июле 2017 года и включают в себя 188 фотографий всех знаков, найденных на улице Баумана - 
центральной улице Казани. Данные были проанализированы по нескольким параметрам: государственные или частные производители знака, количество языков и шрифтов на знаках, языковое предпочтение на основе семиотических особенностей текстов, наличие и тип перевода и транслитерации, типы знаков, типы заведений, тип передаваемой информации и т. д. Результаты показывают, что английский язык интенсивно используется в регионе, особенно на частных знаках, а общее количество текстов на нем превышает количество татарских, несмотря на официальный статус последнего. Тем не менее, английский язык редко служит для передачи сложной информации и в основном ограничивается базовой грамматикой и лексикой, в пользу чего говорят несколько найденных примеров его идиосинкратического употребления. Исследование выявило, что помимо того, что английский язык используется как лингва франка для базовой коммуникации с иностранцами, он также пользуется популярностью среди русско- и татароязычного населения благодаря высокому коммерческому и культурному престижу и тесной ассоциативной связи с высоким качеством и высокими стандартами.

Ключевые слова: языковой ландшафт, Казань, английский язык, русский язык, татарский язык.

Для цитирования: Sharafutdinov I.S. The role of English in the Linguistic Landscape of Kazan // Историческая этнология. 2018. Т. 3, № 2. C. 234-251. DOI: 10.22378/he.2018-3-2.234-251

Сведения об авторе: Шарафутдинов Ильшат Султанович - магистр гуманитарных наук, аспирант отделения Английской Лингвистики Университета Регенсбурга (Universitätsstraße 31, Regensburg 93053, Germany); ilshat.sharafutdinov@stud.uni-regensburg.de 